\title{
INFEKSI OPORTUNISTIK PADA ODHA (ORANG DENGAN HIV/AIDS) TERHADAP KEPATUHAN MINUM ARV (Anti Retroviral) DI KOTA PALEMBANG
}

\author{
Dion Atika Framasari ${ }^{1}$, Rostika Flora ${ }^{2}$, Rico Januar Sitorus ${ }^{2}$ \\ ${ }^{1}$ Mahasiswi program S2 IKM FKM Universitas Sriwijaya, \\ 2Prodi S2 IKM FKM Universitas Sriwijaya, \\ Email: kesmas.dion@gmail.com
}

\begin{abstract}
Background : Human immunodeficiency virus (HIV) is a virus that damages the immune system and CD4 cells. The stronger the virus in destroying CD4 cells, the body has a higher risk for various types of infections and some cancers. There is no cure for HIV / AIDS, but there are several drugs that can reduce or inhibit the multiplication of HIV in the body with antiretroviral therapy (ARV). Opportunistic infections (OI) are the leading cause of death in 90\% of people living with AIDS (Acquired Immunodeficiency Syndrome). The massive increasing number of death from opportunistic infections contributes to AIDS. The purpose of this study was to analysis the relationship of oportunitical infections in PLWHA on arvs compliance within palembang city

Method : This research was an observational study, with a cross sectional study design on februari until maret 2020. Data samples of 235 People with Hiv and Aids (PLWHA) in Palembang were chosen by purposive random sampling.

Results:

The results showed that the proportion of adherence ARV in Palembang was 83\%. respondents found $83 \%$ were male, age ranged between age 26-45 years as much as $72.3 \%$ with the most high school education $48.9 \%$, entrepreneurs $34.5 \%$ and $54 \%$ are single.

There is no significant relationship between opportunistic infections (Ols) experienced by PLWHAs against ARV compliance in the city of Palembang with (Pvalue 0.381;OR:0,675;95\%Cl: 0.328-1.392). There are as many as $62 \%$ of PLWHA who have comorbidities in the form of pulmonary TB out of all who have Ols
\end{abstract}

\section{Conclution :}

opportunitis infections (OIs) are not associated with ARV compliance, pulmonary tuberculosis is an opportunitis infection that was found in many of these studies

Keyword : relationship; adherence; antiretroviral; ARV; HIV;AIDS; oportunistik infections; IO; pulmonary TB

\begin{abstract}
ABSTRAK
Latar belakang: Human immunodeficiency virus (HIV) adalah virus yang merusak sistem kekebalan dan sel CD4. Semakin kuat virus dalam menghancurkan sel CD4, tubuh memiliki risiko lebih tinggi untuk berbagai jenis infeksi. Tidak ada obat untuk HIV / AIDS, tetapi ada beberapa obat yang dapat mengurangi atau menghambat multiplikasi HIV dalam tubuh dengan terapi antiretroviral (ARV). Infeksi oportunistik (OI) adalah penyebab utama kematian pada $90 \%$ orang yang hidup dengan AIDS (Acquired Immunodeficiency Syndrome). Meningkatnya jumlah kematian karena infeksi oportunistik berkontribusi pada AIDS. Tujuan dari penelitian ini adalah untuk menganalisis hubungan infeksi oportunistik terhadap kepatuhan minum ARV pada Orang Dengan HIV dan AIDS (ODHA) di kota palembang
\end{abstract}


Metode: Penelitian ini adalah penelitian observasional, dengan rancangan penelitian cross sectional pada bulan Februari sampai Maret 2020. Sampel data dari 235 ODHA di Palembang dipilih secara purposive random sampling.

Hasil: Hasilnya menunjukkan bahwa proporsi kepatuhan terhadap ARV di Palembang adalah 83\%. sebanyak $83 \%$ adalah laki-laki, usia berkisar antara usia 26-45 tahun sebanyak 72,3\% dengan pendidikan sekolah tinggi 48,9\%, mayoritas Wiraswasta $34,5 \%$ dan $54 \%$ berstatus lajang.Tidak ada hubungan yang signifikan antara infeksi oportunistik (IO) yang dialami oleh Odha dengan kepatuhan ARV di kota Palembang dengan (Pvalue 0,381; OR: 0,675; 95\% Cl: 0,328-1,392). Ada sebanyak 62\% ODHA yang memiliki penyakit penyerta berupa TB paru dari semua yang memiliki $1 \mathrm{O}$

Kesimpulan: infeksi oportunistik (IO) tidak terkait dengan kepatuhan ARV, TB paru adalah infeksi oportunistik yang ditemukan dalam banyak penelitian ini.

Kata kunci: hubungan; ketaatan; antiretroviral; ARV; HIV; AIDS; infeksi oportunistik; IO; TB paru

\section{Pendahuluan}

HIV/AIDS(Human Immuno-deficiency Virus /Acquired Immuno-deficiency Syndrome) telah menjadi masalah darurat global merupakan salah satu penyakit infeksi yang mengancam jiwa sehingga sampai saat ini menjadi perhatian yang cukup serius. Tanpa pengobatan, HIV secara bertahap dapat menghancurkan sistem kekebalan tubuh dan menyebabkan terjadinya AIDS ${ }^{1}$.

Diseluruh dunia, 35 juta orang hidup dengan HIV dan 19 juta orang tidak mengetahui status HIV positif mereka. Dikawasan Asia, sebagian besar angka Prevalensi HIV pada masyarakat umum masih rendah yaitu $<1 \%$, kecuali di Thailand dan India Utara. Pada tahun 2012, di Asia Pasifik diperkirakan terdapat 350.000 orang yang baru terinfeksi HIV dan sekitar $64 \%$ dari yang terinfeksi adalah laki-laki ${ }^{2}$.

Epidemi HIV/AIDS juga menjadi masalah di Indonesia yang merupakan Negara urutan ke 5 paling bersisiko HV/AIDS di Asia $^{3}$. Laporan kasus baru HIV meningkat setiap tahunnya sejak pertama kali dilaporan. Sejak pertarna kali ditemukan tahun 1987 sampai dengan Desember 2018. HIV/AIDS telah dilaporkan oleh 460 (89,5\%) dari 514 kabupaten kota di seluruh provinsi di Indonesia. (2) Jumlah kumulatif infeksi HIV yang dilaporkan sampai dengan Desember 2018 sebanyak 327.282 (51,1\% dari estimasi ODHA tahun 2016 sebanyak 640.443). Jumlah kumulatif AIDS dari tahun 1987 sampai dengan Desember 2018 sebanyak 114. 065 orang 4 .

Di provinsi Sumatera Selatan tercatat sampai dengan juni 2019 jumlah pengidap HIV sebanyak 1.634 penderita HIV dan sebanyak 1790 penderita AIDS. Untuk dikota Palembang sendiri jumlah penderita HIV sampai dengan juni 2019 sebanyak 1.085 penderita. Sementara sebanyak 1.184 penderita AIDS yang tercatat berada dikota Palembang ${ }^{5}$.

Seperti diketahui bahwa infeksi HIV merupakan penyakit kronis yang dapat dikendalikan dengan pemberian obat ARV seumur hidup. Antiretroviral yang sering disebut ARV merupakan satu-satunya obat yang dianggap memberikan manfaat besar dalam menekan perkembangan virus HIV di dalam tubuh. Obat ARV mampu menekan jumlah virus HIV di dalam darah sehingga kekebalan tubuhnya (CD4) tetap terjaga.

Pada waktu yang sama, cakupan antiretroviral therapy (ART) di Indonesia hanya sebanyak 11,7 persen, yang berarti Indonesia adalah salah satu negara yang paling sedikit 
mendapat ART. Dalam penggunaan obat ARV diperlukan tingkat kepatuhan yang tinggi untuk mendapatkan keberhasilan terapi dan mencegah resistensi. Untuk mendapatkan respon penekanan jumlah virus sebesar $85 \%$ diperlukan kepatuhan penggunaan obat 90$95 \%{ }^{6}$.

Sebagai gambaran provinsi Sumatera Selatan sampai dengan juni 2019 ,positif HIV sebanyak 3.474 penderita, yang masuk perawatan ART sebanyak 3.199 penderita, dan yang memulai ART sebanyak 2.469 penderita sementara yang masih bertahan dengan ART sampai dengan juni 2019 hanya sebanyak 1.334 penderita dan ini menunjukkan hanya 42 $\%$ yang masih bertahan dengan ART. Sementara untuk kota Palembang untuk bulan Juni 2019 terdaftar 1180 ODHA dengan ART (hanya $53 \%)^{5}$.

Kepatuhan pasien untuk minum obat ARV adalah hal yang sangat penting untuk dipertimbangkan sebelum memulai pengobatan. Adherence atau kepatuhan artinya bahwa meminum ARV sesuai dengan petunjuk dokter, termasuk di dalamnya: minum obat tepat waktu, sesuai dengan saran dokter dengan makanan atau tanpa makanan, menghindari interaksi obat. Dengan kepatuhan minum obat sesuai dengan petunjuk dokter maka akan memastikan kombinasi ARV yang diminum mempunyai kadar yang cukup dalam darah untuk melindungi diri dalam waktu 24 jam. Jika kadar dalam darahnya menjadi terlalu rendah maka akan meningkatkan resistensi obat. Tujuan utamanya adalah minum obat ARV setiap hari dan tidak pernah lupa sekalipun. Dengan lupa minum obat ARV satu kali atau dua kali seminggu bisa menyebabkan tujuan dari obat menjadi gagal, terutama pada awal pengobatan ${ }^{7}$. Pada tahun-tahun pertama epidemi AIDS, Infeksi oportunistik (IO) merupakan penyebab kematian utama pada penyandang AIDS (Acquired Immunodeficiency Syndrome) persentase $90 \%{ }^{8}$. Kementerian Kesehatan Republik Indonesia melaporkan jumlah kumulatif penderita AIDS (infeksi HIV dengan IO) di Indonesia dari tahun 1987 hingga September 2014 mencapai 55.799, atau sekitar $36,7 \%$ dari keseluruhan kasus HIV ${ }^{9}$. The Joint United Nations Programme on HIV/AIDS (UNAIDS) melaporkan sebanyak 1,2 juta kematian akibat penyakit terkait AIDS sepanjang tahun 2014 dengan penyebab terbanyak (1 dari 5 kematian) diakibatkan oleh tuberkulosis ${ }^{10}$.

Pada tahun 2005, infeksi oportunistik yang dominan muncul pada penyandang AIDS ialah tuberkulosis paru (50\%), hepatitis $(30 \%)$, kandidiasis (25\%), pneumonia (33\%), diikuti oleh diare kronis, dan tuberkulosis ekstra paru11. Infeksi Oportunistik(IO) menyebabkan banyak kesakitan dan kematian. Namun, setelah orang mulai memakai $A R V$, penyakit akibat IO dialami oleh jauh lebih sedikit orang. Angka IO sudah menurun secara dramatis sejak tersedia terapi antiretroviral (ARV). Namun IO masih menimbulkan masalah, terutama untuk orang yang baru diketahui terinfeksi HIV setelah infeksinya lebih lanjut. Banyak orang masih dirawat inap di rumah sakit dengan 10 yang berat ${ }^{12}$.

Tujuan dari penelitian ini adalah untuk menganalisa Infeksi Oportunistik (IO) terhadap Kepatuhan Anti Retroviral (ARV) ODHA di kota Palembang, sehingga diharapkan dari hasil penelitian bisa dijadikan bahan untuk meningkatkan angka kepatuhan ODHA baru ataupun yang lama guna mencapai tujuan yang diinginkan. 


\section{Metode}

Penelitian ini merupakan penelitian observasional dengan desain penelitian deskriptif analitik Rancang bangun penelitian ini adalah cross sectional. Penelitian dilakukan di kota Palembang Provinsi Sumatera Selatan.

Teknik pengambilan sampel dalam penelitian ini adalah dengan cara purposive random sampling, Kota palembang dipilih untuk dijadikan populasi penelitian yang mana dalam mendapatkan ARV para ODHA bisa memanfaatkan beberapa layanan CST yang ada dikota Palembang . yakni berjumlah 8 layanan CST. Masing-masing layanan CST yang berjumlah delapan memiliki pasien ODHA yang berbeda-beda.

Penelitian dilakukan selama bulan Februari dan Maret Tahun 2020. Populasi dalam penelitian ini adalah seluruh ODHA dilayanan CST di Kota Palembang. Sampel dalam penelitian ini adalah ODHA dengan terapi ARV yang memenuhi kriteria inklusi dan lolos dari kriteria eksklusi sebanyak 235 orang. Dengan kriteria inklusi, ODHA dengan domisili kota Palembang, ODHA yang datang melakukan pengobatan dan bersedia mengikuti penelitian. Variabel terikatnya adalah Kepatuhan ARV, sedangkan variabel bebasnya adalah Infeksi Oportunistik (IO).

Sumber data terdiri dari data primer, diperoleh langsung dari hasil survey penelitian. sedangkan teknik pengumpulan data, dengan cara membagikan kuesioner kepada responden. Responden diminta untuk mengisi sendiri kuesioner yang ditunggu dan langsung dikembalikan pada peneliti. dengan meminta persetujuan sebagai responden. Pengolahan Data dilakukan dengan tahapan editing, coding, entry, dan tabulating data, yang dilanjutkan dengan analisis data dengan menggunakan analisis Univariat terhadap variabel yang diteliti.

Hasil

Dari penelitian yang dilakukan dikota Palembang pada bulan Februari dan maret tahun 2020 pada 235 responden diperoleh hasil dengan Analisa univariat, bivariat terhadap variabel independen dengan variabel dependen Berikut adalah hasil analisisnya:

Tabel 1. Distribusi Frekuensi Karakteristik ODHA di Kota Palembang

\begin{tabular}{|c|c|c|}
\hline $\begin{array}{l}\text { Karakteristik } \\
\text { Responden }\end{array}$ & $\mathbf{n}$ & $\%$ \\
\hline \multicolumn{3}{|l|}{ Jenis Kelamin ODHA } \\
\hline Laki- Laki & 195 & 83 \\
\hline Perempuan & 40 & 17 \\
\hline \multicolumn{3}{|l|}{ Usia ODHA } \\
\hline 0-11 tahun & 4 & 1.7 \\
\hline $12-25$ tahun & 32 & 13.6 \\
\hline 26-45 tahun & 170 & 72.3 \\
\hline 46-65 tahun & 29 & 12.3 \\
\hline \multicolumn{3}{|l|}{ Pendidikan ODHA } \\
\hline Tidak Sekolah & 1 & 0.4 \\
\hline Tamat SD & 16 & 6.8 \\
\hline Tamat SMP & 17 & 7.2 \\
\hline Tamat SMA & 115 & 48.9 \\
\hline Tamat PT & 86 & 36.6 \\
\hline \multicolumn{3}{|l|}{ Pekerjaan ODHA } \\
\hline PNS & 12 & 5.1 \\
\hline Pegawai Swasta & 69 & 29.4 \\
\hline Wiraswasta & 81 & 34.5 \\
\hline Buruh & 23 & 9.8 \\
\hline Pelajar/mahasiswa & 11 & 4.7 \\
\hline IRT & 25 & 10.6 \\
\hline Tidak bekerja & 13 & 5.5 \\
\hline Dosen & 1 & 0.4 \\
\hline \multicolumn{3}{|c|}{ Status Marital/Menikah } \\
\hline Menikah & 92 & 39.1 \\
\hline Belum menikah & 127 & 54.0 \\
\hline Janda & 10 & 4.3 \\
\hline Duda & 6 & 2.6 \\
\hline
\end{tabular}


Hasil penelitian menunjukkan bahwa dari total 235 responden didapat $83 \%$ berjenis kelamin laki-laki, usia ODHA berkisar antara umur 26-45 tahun sebanyak $72,3 \%$ dengan Pendidikan terbanyak SMA 48,9\%. ODHA Sebagian besar adala wiraswasta $34,5 \%$ dan status belum menikah sebanyak $54 \%$.

Tabel 2. Distribusi Infeksi Oportunistik (IO)

\begin{tabular}{lcc}
\hline Faktor Risiko & $\mathbf{n}$ & $\%$ \\
\hline Infeksi Oportunitis/IO & & \\
Ya & 66 & 28.1 \\
Tidak & 169 & 71.9 \\
\hline Kepatuhan Terapi ARV & & \\
Patuh >95\% & 195 & 83,0 \\
Tidak Patuh & 40 & 17,0 \\
\hline
\end{tabular}

Proporsi ODHA yang patuh minum ARV $>95 \%$ di kota Palembang sebanyak $83 \%$. Dari responden yang ada 47,2 \% responden mengaku karena mereka lupa sehingga menyebabkan mereka melewatkan dosis obat ARV. Ada sebanyak 28,1 \% ODHA yang mempunyai Infeksi Oportunistik selama menderita HIV dan AIDS.

Table 3. Distribusi Jenis Infeksi Oportunistik (IO)

\begin{tabular}{|c|c|c|}
\hline Faktor Risiko & $\mathbf{n}$ & $\%$ \\
\hline \multicolumn{3}{|c|}{ Infeksi Oportunitis/IO } \\
\hline TB paru & 41 & 62,1 \\
\hline Cryptosporidiosis & 5 & 7,6 \\
\hline Candidiasis/ sifilis & 5 & 7,6 \\
\hline Dll & 15 & 22,7 \\
\hline
\end{tabular}

Hasil penelitian diatas jenis infeksi oportunistik (IO) yang paling banyak tersebar yaitu TB paru sebesar 62,1\% dan Cyrptosporidiosis dan candidiasis masingmasing sebesar 7,6\%. Infeksi ini dapat ditimbulkan oleh patogen yang berasal dari luar tubuh (seperti bakteri, jamur, virus atau protozoa), maupun oleh mikrobiota sudah ada dalam tubuh manusia namun dalam keadaan normal terkendali oleh sistem imun (seperti flora normal usus).10 Penurunan sistem imun berperan sebagai "oportuniti" atau kesempatan bagi patogen tersebut untuk menimbulkan manifestasi penyakit.

\section{Hasil analisis bivariat}

Tabel 3. Distribusi Frekuensi Infeksi Oportunistik (IO) dengan kepatuhan ARV pada ODHA

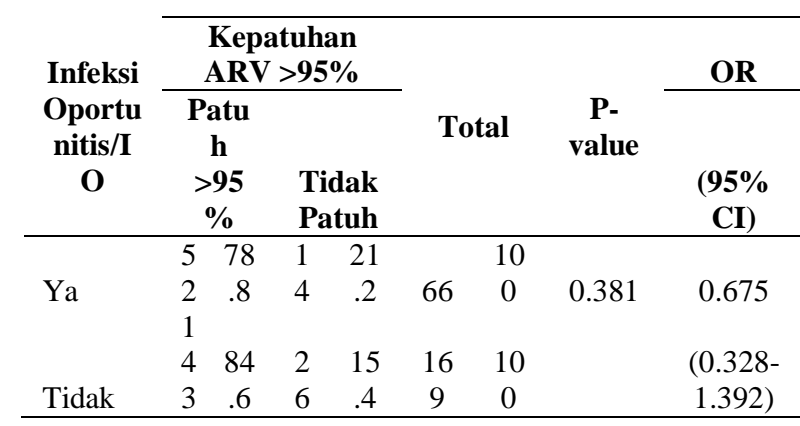

Dari hasil penelitian diatas terlihat bahwa Pvalue 0,381;OR 0,675 dan $\mathrm{Cl}$ 0,3281,392. Ada sebanyak 143 (84,6\% ODHA yang patuh terhadap ARV tidak memiliki Infeksi Oportunistik dan ada sebanyak 14 (21,2\%) ODHA yang tidak patuh ARV memiliki Infeksi Oportunistik.

\section{Pembahasan}

\section{Kepatuhan terapi ARV}

Persentase Kepatuhan ARV dikota Palembang sebesar 83\% (ada 195 responden) dengan status patuh. Dan ada sebanyak $42 \%$ dari responden yang tidak patuh mengaku beralasan lupa minum obat ARV. Hasil penelitian ini sangat sesuai dengan penelitian lainnya yang menunjukkan kepatuhan di negara maju dan berkembang menemukan kesamaan kendala individu pada kepatuhan yaitu lupa memakai obat karena terlalu sibuk mengganggu aktifitas sehari-hari ${ }^{13}$. 
Penelitian yang dilakukan oleh Carter (2012) menyimpulkan bahwa kepatuhan adalah faktor yang paling penting memengaruhi keberhasilan virologi terapi HIV ${ }^{14}$. Hasil terbaik terlihat pada pasien yang menggunakan semua/hampir semua dosis obat mereka dengan benar dan memiliki tingkat kepatuhan yang sempurna . Pengobatan menggunakan terapi ARV dilakukan seumur hidup, oleh karena itu dibutuhkan tingkat kepatuhan yang tinggi dalam hal mengonsumsi obat (>95\%). Kepatuhan dalam pengobatan diperlukan untuk menurunkan replikasi virus dan memperbaiki kondisi klinis dan imunologis, menurunkan timbulnya resistansi ARV, dan menurunkan resiko transmisi HIV ${ }^{15}$.

Hampir Sebagian besar ODHA pada penelitian ini $97,4 \quad \% \quad$ mempunyai persepsi/mempercayai bahwa dengan meminum obat ARV, hidup mereka akan bertahan lebih lama.ini merupakan salah satu factor pendorong mereka untuk tetap Patuh minum ARV.

Kepatuhan adalah minum obat sesuai dosis tidak pernah lupa, tepat waktu, dan tidak pernah putus. Kepatuhan dalam meminum ARV mrupakan factor terpenting dalam menekan jumlah virus HIV dalam tubuh manusia. Penekanan jumlah virus yang lama dan stabil bertujuan agar system tubuh imun tetap terjaga tinggi. Dengan demikian, oraang yang terinfeksi virus HIV akan mendapatkan kualitas hidup yang baik dan juga mencegah terjadinya kesakitan dan kematian. Salah satu hal yang perlu dipahami dalam meningkatkan tingkat kepatuhan adalah pasien memerlukan dukungan bukan disalahkan ${ }^{16}$

\section{Infeksi Oportunistik (IO) pada ODHA}

Infeksi oportunistik (IO) adalah infeksi yang mengambil kesempatan dari kelemahan dalampertahanan kekebalan tubuh manusia. Ada sebesar 62\% ODHA yang mempunyai penyakit penyerta nya berupa TB paru dari keseluruhan yang memiliki 10 terlihat pada grafik diatas. Dan ini sesuai dengan pernyataan dari NSW Health Factsheet - Indonesian dalam The connection between TB and HIV , Dari 40 juta orang yang diperkirakan sedang hidup dengan HIV atau AIDS, kurang lebih 13 juta juga menderita $\mathrm{TBC}^{17}$. Penelitian di Rumah Sakit Umum Daerah Wangaya Denpasar Bali pada tahun 2014 yang mendapatkan IO tersering adalah TB, Toksoplasmosis, kandidiasis oral, 10 multipel dan pneumonia ${ }^{18}$.

Tuberkulosis(TB) merupakan salah satu infeksi paling sering pada penderita HIV/AIDS. Akibat kerusakan cellular immunity oleh infeksi HIV menyebabkan berbagai infeksi oportunistic, seperti TB. Angka kematian akibat infeksi TB pada penderita HIV lebih tinggi, TB merupakan penyebab kematian tersering (30-50\%) pada penderita HIV/AIDS. HIV tidak hanya membuat diagnosis TB menjadi sulit, tetapi juga meningkatkan insidens TB. Angka kejadian TB lebih besar pada orang dengan HIV dibandingkan pada orang tanpa $\mathrm{HIV}^{19}$. Dibandingkan dengan orang tanpa HIV, ODHA mempunyai risiko 20 kali untuk menderita TB dan risiko ini akan terus meningkat seiring dengan kadar CD4 yang menurun secara drastic Penurunan CD4 yang terjadi dalam perjalanan penyakit infeksi HIV akan mengakibatkan reaktivasi kuman TB yang dorman ${ }^{20}$. 


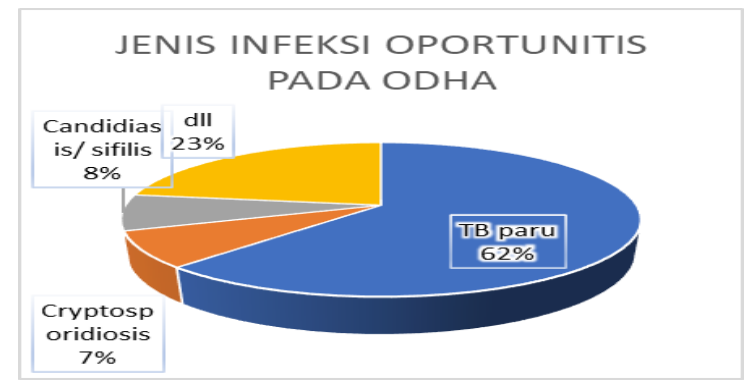

Gambar 1. Distribusi Jenis Infeksi Oportunistis pada ODHA di kota Palembang

Tuberkulosis merupakan infeksi oportunistik tersering (40\%) pada infeksi HIV dan menjadi penyebab kematian paling tinggi pada ODHA ${ }^{10,21}$. Infeksi TB dan HIV saling berhubungan, HIV menyebabkan progresivitas infeksi TB menjadi TB aktif, sebaliknya infeksi TB membantu replikasi dan penyebaran HIV serta berperan dalam aktivasi infeksi HIV yang laten $^{22}$. Sebagian besar orang yang terinfeksi kuman TB tidak menjadi sakit TB karena mempunyai sistem imun yang baik, dan dikenal sebagai infeksi TB laten. Infeksi TB laten tersebut tidak infeksius dan asimtomatis, namun dengan mudah dapat berkembang menjadi TB aktif pada orang dengan sistem imun yang menurun, seperti pada ODHA ${ }^{23,21}$. Pasien TB dengan HIV positif atau ODHA dengan TB disebut sebagai pasien ko-infeksi TB-HIV. Berdasarkan perkiraan WHO, jumlah pasien koinfeksi TB-HIV di dunia adalah sebanyak 14 juta orang, dengan 3 juta pasien terdapat di Asia Tenggara. Epidemi HIV sangatlah berpengaruh pada meningkatnya kasus TB sehingga pengendalian TB tidak akan berhasil dengan baik tanpa upaya pengendalian HIV ${ }^{21}$.

Infeksi Oportunistik (IO) dengan Kepatuhan Terapi ARV pada ODHA

Berdasarkan hasil penelitian uji chi square didapatkan $p=0.381$ ( $p>0,05)$. Hasil ini menunjukkan bahwa tidak ada hubungan yang signifikan antara penyakit penyerta (Kormobiditas/infeksi oportunistik (IO)) dan tingkat kepatuhan ARV .

Penelitian ini berbeda dengan yang dilakukan oleh Risha Fillah, dkk. (2010) dengan nilai signifikansi $0,049(<0,05)$ yang

berarti faktor infeksi oportunistik yang menyebabkan responden merasa kondisinya semakin parah berpengaruh secara signifikan terhadap tingkat kepatuhan pengobatan ARV24. Data berbagai penelitian mendapatkan bahwa ART menurunkan insiden IO secara drastis, membantu resolusi dan perbaikan $\mathrm{IO}$, termasuk IO yang profilaksis dan terapi spesifiknya belum tersedia. ${ }^{25}$ Terapi antiretroviral tidak dapat menggantikan kebutuhan terhadap profilaksis antimikrobial pada pasien dengan imunosupresi yang berat, namun telah menjadi landasan strategi untuk menurunkan berbagai infeksi dan proses terkait HIV ${ }^{26}$.

\section{Kesimpulan}

Berdasarkan hasil penelitian dapat disimpulkan bahwa tidak ada hubungan yang bermakna antara infeksi oportunistik(IO) yang dialami odha terhadap Kepatuhan ARV dikota Palembang dengan P-value 0.381 .

Ada sebanyak 62\% ODHA yang mempunyai penyakit penyerta nya berupa TB paru dari keseluruhan yang memiliki IO. 


\section{DAFTAR PUSTAKA}

1. AIDSinfo. (2017). HIV/AIDS: The Basics. Retrieved September 25,2017,from https://aidsinfo.nih.gov/understanding-hiv-aids/factsheets/19/45/hiv-aids--the-basics

2. Unaids. 2013. Unaids report 2013:HIV in Aisa and Pasific.

3. Kemenkes RI. 2014. Peraturan Menteri Kesehatan No. 87 tahun 2014 tentang Pedoman Pengobatan Retroviral. Menteri Kesehatan Republik Indonesia. Jakarta

4. depkes.go.id . 2018 Laporan_Triwulan_IV_2018 Available on line at http://siha.depkes.go.id/portal/files_upload/Laporan_Triwulan_IV_2018.pdf htm. Diakses pada 4 November 2019

5. Laporan semester program HIV dan AIDS Dinas Kesehatan Kota palembang sumsel 2019

6. Martoni, W. 2012. Faktor-faktor yang mempengaruhi kepatuhan pasien HIV/AIDS di poliklinik khusus rawat jalan bagian penyakit dalam RSUP Dr. M. Djamil Padang periode Desember 2011-Maret 2012

7. Permenkes RI no 87 tahun 2014. Pedoman Pengobatan Anti retroviral. (ARV).

8. Onyancha B. An informetric investigation of the relatedness of opportunistic infections to HIV/AIDS. Information Processing and Management. 2005; 41(1):1573-88.

9. Direktorat Jenderal Pengendalian Penyakit dan Penyehatan Lingkungan Kementerian Kesehatan Republik Indonesia. Situasi dan analisis HIV/AIDS. Pusat Data dan Informasi Kementerian Kesehatan Republik Indonesia; 2014. p. 1-8.

10. The Joint United Nations Programme on HIV/AIDS. Global AIDS statistic 2014. World Health Organization; 2015. p. 1-8. 2.

11. Astoro N, Djauzi S, Djoerban Z, Prodjosudjadi W. Kualitas hidup penderita HIV dan faktor-faktor yang mempengaruhi. Jakarta: Balai Penerbit FKUI; 2003.

12. Infeksi oportunistik available on http://www.aidsinfonet.org/uploaded/factsheets/87 ind 500.pdf

13. Keith alcorn: bagaimana memberi kepatuhan yang baik. Pengalaman dari seluruh dunia. $\mathrm{Http} / /$ spiritia.or.id

14. Carter, M. 2012.Penghentian pengobatanmelibatkan risiko kegagalan virologi yang lebih tinggi dibandingkan dosis yang dilewatkan

15. sesekali http://spritia.or.id/news/bacanews.php?nwno=2944.

16. Kemenkes RI. 2014. Peraturan Menteri Kesehatan No. 87 tahun 2014 tentang Pedoman Pengobatan Retroviral. Menteri Kesehatan Republik Indonesia. Jakarta

17. World Health Organization, 2003, Adherence to Long-Term Therapies, Switzerland.

18. Ariani W., Arya L.N., Suryana K. "Spektrum infeksi oportunistik pada klien Klinik Merpati RSUD Wangaya periode Januari-Februari 2014." E-Jurnal Medika Udayana. 2015; 4(2): 1-7.

19. Departemen Kesehatan NSW www.health.nsw.gov.au/PublicHealth/Infectious/TB/index.asp

20. Narain P, Lo YR. Epidemiology of HIV-TB in Asia. Indian J Med Res. 2004; 120, pp 277-289. March8,2016.https://search.proquest.com/openview/d8550ddc0443b9a1ff74f278eedf991 c/1 ?pqorigsite= gscholar\&cbl=37533 4 .

21. Direktorat Jenderal Pengendalian Penyakit dan Penyehatan Lingkungan Kementerian Kesehatan Republik Indonesia. Petunjuk tehnis tatalaksana klinis ko-infeksi TB-HIV. Kementerian Kesehatan Republik Indonesia; 2012. p. 1-150

22. Sandhu, A., Samra, A.K. Opportunistic infections and disease implications in HIV/AIDS. IJPSI. 2013; 2(5): 47-54.

23. Panel on Opportunistic Infections in HIV-Infected Adults and Adolescents. Guidelines for the prevention and treatment of opportunistic infections in HIV-infected adults and adolescents: recommendations from the Centers for Disease Control and Prevention, the National Institutes of Health, and the HIV Medicine Association of the Infectious Diseases Society of America. Department of Health and Human Services; 2015. p. 1-441.

24. Risha Fillah Fithria1, Ahmad Purnomo2, Zullies Ikawati3. Faktor-Faktor Yang Mempengaruhi Tingkat Kepatuhan Pengobatan Arv (Anti Retro Viral) Pada Odha (Orang Dengan Hiv/Aids) Di Rumah Sakit Umum Daerah Tugurejo Dan Rumah Sakit Umum Panti Wilasa Citarum Semarang. Jurnal Manajemen Dan Pelayanan Farmasi. Vol. 1 No. 2 / Juni 2011

25. Kaplan, J.E., Masur H. Preventing opportunistic infections among HIVinfected persons. In: Holmes, K.K., Sparling, P.F., Stamm, W.E., Piot, P., Wasserheit, J.N., Corey, L., Cohen, M.S., Watts, D.H., eds. Sexually Transmitted Diseases. 4th ed. New York: McGraw-Hill; 2008. p. 142341.

26. Benson, C.A., Kaplan, J.E., Masur, H., Pau, A., Holmes, K.K. Treating opportunistic infections among HIV-infected adults and adolescents: recommendations from CDC, the National Institutes of Health, and the HIV Medicine Association/Infectious Diseases Society of America. MMWR. 2004; 53(RR-15): 1-112. 